\title{
Meningkatkan Kesadaran Hukum melalui Pembelajaran Ilmu Hukum di Perguruan Tinggi
}

\author{
Rita Angraini, Muhammad Prima Ersya, Irwan, Atri Waldi, Zaky Farid Luthfi, Monica Tiara \\ Program Studi Pendidikan Pancasila dan Kewarganegaraan \\ Universitas Negeri Padang \\ Email : angrainirita15@gmail.com
}

\begin{abstract}
ABSTRAK
Orientasi utama pembelajaran ilmu hukum adalah untuk meningkatkan kesadaran hukum mahasiswa yang memiliki sikap taat dan patuh terhadap peraturan yang berlaku. Namun kenyataannya berdasarkan observasi ditemukan bahwa cukup banyak mahasiswa yang tidak memiliki kesadaran terhadap peraturan-peraturan di kampus dan di masyarakat. Penelitian ini menggunakan pendekatan kualitatif, berusaha menjawab permasalahan bagaimanakah gambaran pembelajaran ilmu hukum dalam meningkatkan kesadaran hukum mahasiswa prodi PPKn Universitas Negeri Padang dan upaya yang dapat dilakukan dalam meningkatkan kesadaran hukum. Teknik pengumpulan data adalah melalui observasi, wawancara dan penyebaran angket. Hasil penelitian menemukan bahwa mahasiswa PPKn sebagian besar setuju bahwa dengan adanya pembelajaran ilmu hukum mampu memberikan pengetahuan, pemahaman, sikap dan perilaku hukum. Dan upaya yang dapat dilakuan untuk meningkatkan kesadaran hukum adalah melalui tindakan hukum, pendidikan dan kampanye hukum.
\end{abstract}

Kata Kunci: Pembelajaran, Ilmu Hukum, Kesadaran Hukum

\section{ABSTRACT}

The main orientation of learning law is to increase the legal awareness of students who have an obedient and compliant attitude towards applicable regulations. But the reality is based on observations found that quite a lot of students who do not have awareness of the rules on campus and in the community. This study uses a qualitative approach, trying to answer the problem of how is the picture of learning law in increasing the legal awareness of PPKn students at Padang State University and the efforts that can be made in increasing legal awareness. Data collection techniques are through observation, interviews and questionnaires. The results of the study found that most PPKn students agreed that the study of legal knowledge was able to provide knowledge, understanding, attitudes and legal behavior. And efforts that can be taken to increase legal awareness are through legal action, education and legal campaigns

Keywords : Learning, legal studies, legal awareness

This work is licensed under the Creative Commons Attribution-ShareAlike 4.0 International License. @2019 by author and Universitas Negeri Padang. 


\section{PENDAHULUAN}

Pembelajaran merupakan rangkaian proses yang dilakukan untuk memungkinkan terjadinya aktivitas belajar. Dalam hal ini aktivitas belajar meliputi kegiatan pembuka, kegiatan inti dan kegiatan penutup dalam pembelajaran. Pada dasarnya proses pembelajaran meliputi aspek kognitif, afektif dan psikomotorik. Aspek kognitif dapat kita lihat pada kemampuan dalam memahami materi pelajaran, aspek afektif adalah pembentukan sikap setelah memahami suatu materi dan aspek spikomotorik adalah keterampilan yang dimiliki atau penerapannya setelah memahami suatu materi pelajaran.

Pembelajaran yang efektif adalah ketika tujuan pembelajaran bisa tercapai. Tujuan ini dapat dilihat dari tingkah laku yang dapat diukur atau kompetensi yang harus dimiliki. Tingkah laku dapat dilihat dari sikap yang dimunculkan baik dalam proses pembelajaran maupun diluar proses pembelajaran. Sedangkan capaian kompetensi dapat dilihat dari kemampuan mengulangi kembali materi yang telah dipelajari (rote learning) dan belajar dapat dikatakan berhasil manakala mampu menyampaikan dan mengekspresikan materi pelajaran yang telah dipelajari dengan bahasa sendiri (over learning), dengan demikian proses pembelajaran yang terjadi lebih bermakna (meaning full).

Hal ini tidak jauh berbeda dengan pembelajaran ilmu hukum yang diberikan di program studi pendidikan Pancasila dan Kewarganegaraan Universitas Negeri Padang, orientasi utama pembelajaran ini adalah untuk memunculkan kesadaran hukum mahasiswa yang memiliki sikap taat dan patuh terhadap peraturan yang berlaku setelah mendapatkan pembelajaran ilmu hukum. Farhana (2018: 214) menjelaskan hukum dipahami sebagai aturan yang kaku dan terlalu banyak penekanan pada aspek hukum dari sistem hukum atau penekanan aspek legitimasi aturan itu sendiri, sehingga untuk memunculkan kesadaran hukum pada masyarakat cukup sulit. Hal senada juga diungkapkan oleh Hamzah (2018:215) menjelaskan bahwa untuk memunculkan kesadaran hukum pada peserta didik hendaklah dalam pendidikan hukum harus bebas dari pengaruh elit politik dan praktik birokrasi.

Hal ini juga dikemukakan oleh Suparman bahwa kesadaran hukum dalam pengertian yang sempit ialah yang diketahui orang tentang apa yang demi hukum harus dilakukan, harus tidak dilakukan dan tidak harus dilakukan. "Sadar" diartikan sebagai menjadi tahu. Dalam pengertian luas, kesadaran hukum meliputi tidak hanya fenomena sudah menjadi tahu, akan tetapi juga lebih lanjut menjadi sudah berkemantapan hati untuk mematuhi apa yang diperintahkan oleh hukum. Dengan kataatan, dalam hati yang lebih luas ini apa yang disebut kesadaran itu tidak hanya akan meliputi dimensi kognitif'saja akan tetapi juga dimensi afektif.

Kesadaran dalam arti sempit menjadi tahu itu terjadi karena proses pengkhabaran, pemberitahuan dan pengajaran. Lewat proses-proses ini orang menjadi tahu isi normative yang 
terkandung di dalam kaidah-kaidah hukum, dan sehubungan dengan itu ia akan segera menyesuaikan segala perilakunya ke tuntutan-tuntutan kaidah. Proses pengkhabaran dan pengajaran semacam itu acap kali berlanjut dalam proses pendidikan ialah proses pembangkitan rasa patuh dan setia. Pendidikan tidak hanya menanamkan pengetahuan baru saja, akan tetapi juga hendak menggugah perasaan dan membentuk sikap positif. Hal senada juga diungkapkan oleh Kalivoski (2016:65) menjelaskan bahwa untuk membentuk kepatuhan terhadap hukum dapat dilakukan melalui sosialisasi hukum yakni proses dimana kaum muda mengembangkan keyakinan dalam legitimasi hukum dan sistem hukum. Gostev (2016:11195) juga menjelaskan bahwa untuk memunculkan kesadaran hukum diperlukan adanya peningkatan sistematis dalam peraturan perundang-undangan disektor pendidikan. Pada dasarnya hukum membawa pengaruh yang cukup besar dan memberikan peran yang semakin penting dalam rangka memunculkan kesadaran hukum dalam kehidupan kampus (Nguyen: 2018:126). Hal berbeda diungkapkan oleh Corro (2018: 72) menjelaskan bahwa untuk memunculkan kesadaran hukum diperguruan tinggi dapat memerapkan pembelajaran yang memungkinkan secara digital diruang kelas, namun juga dibarengi dengan penigkatan pedagogis tertentu.

Pembelajaran ilmu hukum di prodi PPKn diberikan kepada mahasiswa setiap semester, pada semester pertama mahasiswa mendapatkan 1 (satu) mata kuliah hukum yakni: pengantar ilmu hukum, semester kedua mendapatkan 3 (tiga) mata kuliah hukum yaitu: pengantar hukum Indonesia, hukum adat dan hukum islam, semester ketiga juga ada 3 (tiga) mata kuliah hukum yakni: hukum pidana, hukum tata negara, dan hukum dan HAM, semester keempat ada 2 mata kuliah hukum yakni: hukum perdata dan hukum dan peradilan internasional, serta semester kelima mendapatkan 2 (dua) mata kuliah hukum yakni: hukum acara dan sosiologi hukum.

Dari penyebaran mata kuliah hukum yang diberikan kepada mahasiwa tiap semester, penulis beranggapan bahwa pembelajaran ilmu hukum yang diberikan akan mempengaruhi tingkat kesadaran hukum mahasiwa, semakin banyak mahasiwa mendapatkan pembelajaran ilmu hukum seharusnya semakin tinggi tingkat kesadaran patuh kepada peraturan atau hukum yang berlaku baik itu di kampus maupun di lingkungan sebagai masyarakat dan warga negara. Perilaku tersebut dapat dilihat dari gaya berpakaian mahasiswa yang sesuai dengan aturan dari institusi, memarkir kendaraan pada tempatnya, tidak membuka situssitus terlarang dan mematuhi ramburambu lalu lintas. Namun kenyataannya berdasarkan observasi yang telah penulis lakukan diperoleh data bahwa cukup banyak mahasiswa yang tidak mematuhi aturan-aturan yang berlaku baik di lingkungan kampus maupun di lingkungan masyarakat. Artikel ini bertujuan untuk mendeskripsikan gambaran pembelajaran ilmu hukum dalam menumbuhkan kesadaran hukum dan upaya yang dapat dilakukan dalam 
menumbuhkan kesadaran hukum mahasiswa prodi PPKn FIS UNP.

\section{Kesadaran Hukum}

Kesadaran hukum merupakan konsep di dalam sosiologi hukum yang memiliki berbagai pengertian. Kesadaran hukum sebenarnya merupakan kesadaran atau nilai-nilai yang terdapat di dalam diri manusia tentang hukum yang ada atau tentang hukum yang diharapkan ada. Fokus yang ditekankan adalah nilai-nilai tentang fungsi hukum dan bukan suatu penilaian hukum terhadap kejadian-kejadian yang kongkrit dalam masyarakat yang bersangkutan.

Ada 4 dimensi-dimensi kesadaran hukum menurut B.Kutchinsky dalam Soekanto :

1. Pengetahuan tentang peraturan-peraturan hukum (law awareness) adalah: awareness of the very fact that a certain type of behavior is regulated by law (kesadaran terhadap kenyataan bahwa jenis perilaku tertentu diatur oleh hukum)

2. Pemahaman tentang isi peraturan-peraturan hukum (law acquaintance) adalah: the amount of information a person has about the content matter of a certain normative regalation (sejumlah informasi yang dipunyai seseorang yang mengandung muatan perkara terhadap peraturan normatif tertentu)

3. Sikap terhadap peraturanperaturan hukum (legal attitude) adalah: a disposition to accept some legal norm or precept because it deserves respect as valid piece of law (suatu kecenderungan untuk menyetujui suatu norma hukum atau aturan karena pantas dipatuhi sebagai bagian hukum yang berlaku) dan a tendency to accept the legal norm or precept because it is appreciated as advantageous or useful (suatu kecenderungan untuk menyetujui suatu norma hukum atau aturan karena dinilai sebagai suatu keuntungan atau kemanfaatan)

4. Perilaku hukum (legal behaviour) adalah: legally desidered behavior (perilaku yang diinginkan secara hukum).

Setiap dimensi tersebut dapat menunjukkan tingkat kesadaran hukum dari tingkat yang terendah yaitu law awareness sampai tertinggi yaitu legal behaviour.

\section{Kepatuhan Hukum}

Kepatuhan hukum menurut Satjipto Rahardjo (2009:71) adalah dimana terdapat kesesuaian antara perbuatan dengan yang dikehendaki oleh teks dalam hal ini adalah perundang-undangan. Dasar-dasar kepatuhan sendiri menurut Bierstedt dikutip Soekanto adalah indoctrination (indoktrinisasi), habituation (kebiasaan), utility (kemanfaatan) dan group identification (penanda kelompok). Lalu Soekanto mengkaitkan dasar tersebut dengan kepatuhan hukum. Sebab pertama mengapa masyarakat mematuhi hukum adalah karena ia diindoktrinir untuk berbuat demikian, karena sejak kecil mengalami proses sosialisasi, maka lama kelamaan menjadi suatu kebiasaan untuk mematuhi kaedah-kaedah yang berlaku, dengan demikian maka salah satu faktor yang menyebabkan orang taat pada kaedah adalah karena kegunaan dari pada kaedah tersebut, 
salah satu mengapa seseorang patuh pada kaedah adalah karena kepatuhan tersebut merupakan salah satu sarana untuk mengadakan identifikasi dengan kelompok.

Derajat kepatuhan hukum menurut H.C Kelman dapat dibedakan dalam 3 proses yaitu:

1. Complianci diartikan sebagai suatu kepatuhan yang didasarkan pada harapan akan suatu imbalan dan usaha untuk menghindarkan diri dari hukuman yang mungkin dijatuhkan.

2. Identification terjadi apabila kepatuhan terhadap kaedah hukum ada bukan karena nilai intrinsinya, akan tetapi agar keanggotaan kelompok tetap terjaga serta ada hubungan baik dengan mereka yang diberi wewenang untuk menerapkan kaedah-kaedah hukum tersebut.

3. Internalization diartikan ketika seseorang mematuhi kaedah hukumoleh karena intrinsik kepatuhan tadi mempunyai imbalan dan isi kaedah tersebut sesuai dengan nilai-nilainya sejak semula pengaruh terjadi, atau oleh karena dia mengubah nilai-nilai tang semula dianutnya. (Soekanto, 1982:230).

G.P Hoefinagels dikutip Soekanto juga mengklasifikasikan beberapa derajat kepatuhan hukum sebagai berikut:

a. Seseorang berperilaku sebagaimana diharapkan hukum dan menyetujui sesuai dengan sistem nilainilai dari mereka yang berwenang.

b. Seseorang berperilaku sebagaimana diharapkan oleh hukum dan menyetujui, akan tetapi dia tidak setuju dengan penilaian yang diberikan oleh yang berwenang terhadap hukum yang bersangkutan

c. Seseorang mematuhi hukum, akan tetapi dia tidak setuju dengan kaedah-kaedah tersebut maupun pada nilai-nilai dari penguasa

d. Seseorang tidak patuh pada hukum, akan tetapi dia menyetujui hukum tersebut dan nilai-nilai dari mereka yang mempunyai wewenang

e. Seseorang sama sekali tidak menyetujui kesemuanya dan dia pun tidak patuh pada hukum (melakukan protes).

Adapun hubungan kesadaran hukum dengan kepatuhan hukum menurut Satjipto Rahardjo bahwa dalam pikiran yuridis tradisional menybutkan bahwa perilaku orang itu dibentuk oleh peraturan hukum dan antara peraturan hukum dan kepatuhan hukum terdapat hubungan linear yang mutlak (2010:203). Hal ini dibantah oleh Sumner dikutip Rahardjo (2010:203) yang menyatakan bahwa perundang-undangan tidak mempunyai pengaruh langsung atau berpengaruh sedikit saja terhadap perilaku. Salah satu faktor yang mempengaruhi perilaku yang sesuai hukum atau kepatuhan hukum menurut penulis adalah faktor kesadaran hukum. Hal ini seperti yang diungkapkan oleh B. Kutchinsky dikutip Soekanto bahwa kesadaran hukum yang kuat menjadi pertimbangan yang menyebabkan kepatuhan terhadap hukum sementara kesadaran hukum yang lemah menjadi pertimbangan yang menyebabkan kriminalitas dan kejahatan.

Dari peryataan tersebut diketahui bahwa ada hubungan yang 
signifikan antara kesadaran hukum dan kepatuhan hukum masyarakat secara umum. Namun demikian seperti telah dijelaskan sebelumnya bahwa konsep kesadaran hukum memiliki empat yang perlu dipaparkan secara lebih spesifik terkait hubungan dengan konsep kepatuhan.

a. Pengetahuan Hukum dan Kepatuhan Hukum

$$
\text { Hubungan pengetahuan }
$$
hukum dengan kepatuhan hukum menurut Kutchinsky adalah bahwa pengetahuan hukum bukanlah sebuah kondisi yang perlu maupun kondisi yang cukup baik untuk tunduk pada hukum. Dengan demikian dapat disimpulkan bahwa tak ada pengaruh positif maupun negatif dari pengetahuan hukum terhadap kepatuhan hukum. Walaupun dianggap tidak ada pengaruh yang signifikan, Yusron Razak (2008) berpendapat bahwa kurangnya informasi (pengetahuan) adalah salah satu faktor yang mempengaruhi konfirmasi atau perilaku yang sesuai dengan harapa kelompok. Dengan demikian dapat dikatakan bahwa ada pengaruh pengetahuan terhadap kepatuhan sesesorang walaupun signifikansinya masih dalam perdebatan.

b. Pemahaman Isi Hukum dan Kepatuhan Hukum

Pemahaman isi hukum adalah konsep yang berbeda dengan pengetahuan hukum, karena terkadang seseorang mengetahui bahwa ada suatu aturan namun tidak memahami isinya atau sebaliknya. Terkait dengan kepatuhan hukum, konsep pemahaman isi hukum menurut Soekanto menyatakan bahwa pengetahuan tentang isi peraturan mempunyai pengaruh yang positif terhadap kepatuhan hukum disebabkan karena proses imitasi dan internalisasi, dan masih perlu diperhitungkan tentang masalah peranan penegak hukum.

Dari pernyataan tersebut dapat diketahui bahwa terdapat pengaruh yang signifikan antars pemahaman isi hukum terhadap kepatuhan hukum.

c. Sikap Hukum dan Kepatuhan Hukum

Hubungan sikap hukum terhadap kepatuhan hukum dapat diketahui dari pernyataan A.Podgoresky dikutip Soekanto yang melihat perbedaan antara sikap fundamental yaitu kecenderungan untuk menyetujui suatu norma hukum atau aturan hukum karena pantas dipatuhi sebagai sebuah bagian sah dari hukum dan sikap instrumental yaitu kecenderungan untuk menyetujui norma hukum atau aturan karena itu dinilai sebagai keuntungan atau kegunaan. Berarti kepatuhan hukum berdasarkan sikap hukum yang instrumental bereaksi dengan memperhitungkan untung-ruginya suatu aturan hukum terhadap individu tersebut. Sedangkan kepatuhan hukum berdasarkan sikap hukum yang fundamental bereaksi dengan didasari tanpa mementingkan kepentingan pribadi dan hal itu dianggap sebagai sikap yang mantap.

Jadi hubungan sikap hukum dengan kepatuhan hukum menurut Soekanto adalah sikap secara menyeluruh mempengaruhi kepatuhan tidaklah dapat diragukan lagi. Dengan kata lain dapat dikatakan bahwa sikap hukum berpengaruh 
berarti terhadap kepatuhan hukum masyarakat.

d. Pola Perilaku Hukum dan Kepatuhan Hukum

Hubungan pola perilaku hukum dan kepatuhan hukum sangat erat, karena menurut Soekanto bahwa setiap perilaku yang sesuai dengan hukum merupakan salah satu ciri akan adanya kepatuhan hukum yang cukup tinggi. Dengan demikian dapat disimpulkan bahwa pola perilaku hukum berpengaruh secara signifikan terhadap kepatuhan hukum.

Dari penjelasan tersebut jelaslah bahwa kesadaran hukum dengan dimensi-dimensi di dalamnya dapat dihubungkan dengan aturan hukum itu dipatuhi atau tidak oleh masyarakat.

Kesadaran hukum dan kepatuhan hukum masyarakat dapat dikaji dengan pespektif sosiologis tentang fakta sosial. Fakta sosial menurut para sosiolog itu bersifat umum, memaksa dan eksternal (di luar individu). Fakta sosial menurut Durkheim terdiri atas dua macam yaitu:

1. Dalam bentuk material, yaitu barang sesuatu yang dapat disimak, ditangkap dan diobservasi. Fakta sosial yang berbentuk amterial ini adalah bagian dari dunia nyata contohnya norma hukum.

2. Dalam bentuk nonmaterial yaitu sesuatu yang dianggap nyata, bersifat intersubjective yang hanya muncul dari dalam kesadaran manusia. Contohnya: egoisme, altruisme, dan opini.
Dengan kata lain, pengaruh pranata sosial dalam hal ini negara atau masyarakat dalam terwujudnya kesadaran dan kepatuhan terhadap hukum yang berlaku sangat berpengaruh. Cara pranata sosial mempengaruhi dapat dilakukan dengan cara sosialisasi sebagimana Adlers dk menyatakan bahwa “ sosialisasi memainkan peranan yang sangat penting dalam cara kita berfikir dan bertindak, dengan kata lain pada tingkat yang sangat besar pengaruh sosial yang dialami setiap orang menentukan perilaku mereka. Entah itu, apakah seseorang menjadi patuh hukum atau melakukan kejahatan. Maka hal itu tergantung pada kontak dengan nilai-nilai, defenisi, dan polapola perilaku seseorang terhadap tindak kejahatan.

Selain itu kesadaran dan kepatuhan terhadap hukum juga merupakan perilaku yang dapat dipelajari dengan berbagai cara seperti perilaku-perilaku lainnya. Cara-cara ini sebagaimana dijelaskan oleh adler dkk sebagai berikut:

1. Observational Learning, Albert Bandura berpendapat bahwa individu mempelajari kekerasan dan agresi melalui behavioral modelling. Perilaku ditranmisikan melalui contoh yang bersumber pada: keluarga, peer group, subkultur, dan media massa.

2. Direct Experience, apa yang dipelajari dengan pengalaman langsung didasarkan pada apa yang terjadi pada individu sendiri atau apa yang individu pernah lakukan.

3. Differencial Reinforcement, Burgess \& Akers mengkombinasikan teori psikologi Bandura dengan teori 
differencial association milik Sutherland untuk memproduksi teori differencial association reinforcement, teori ini menyatakan bahwa 1 . Kuatnya tindak kriminal terletak pada apakah ada atau tidak adanya penghargaan atau hukuman, dan 2. Banyaknya cara \& tujuan yang diberikan hadiah dan hukuman yang diberikan oleh kelompok merupakan penting dalam kehidupan individu.

Walaupun norma hukum dan norma-norma yang lain menurut paradigma fakta sosial mengkontrol perilaku individu manusia. Namun demikian, Coleman (2008:296) menyatakan bahwa orang-orang yang tindakannya tunduk pada norma tentunya mempertimbangkan normanorma tersebut, imbalan atau hukuman yang potensial yang menyertainya bukan sebagai faktor penentu mutlak tindakannya, tetapi sebagai elemen yang mempengaruhi keputusannya tentang tindakan apa saja yang akan dilakukan demi kepentingannya

Dengan demikian dapat dikatakan bahwa individu bukanlah aktor yang pasif yang tindaknnya selalu dikendalikan oleh sesuatu yang ada di luar individu melainkan aktor yang aktif dan kreatif dalam menentukan cara dan intrument untuk mencapai tujuannya..

\section{METODE PENELITIAN}

Artikel ini ditulis berdasarkan hasil penelitian yang bersifat deskriptif kualitatif, namun dalam pengumpulan data selain melalui observasi dan wawancara juga dengan penyebaran angket, hasil analisis angket dinterpretasikan secara kualitatif. Pengumpulan data penelitian dilakukan pada bulan September 2018, adapun informan dalam penelitian ini adalah mahasiswa Pogram Studi Pendidikan Pancasila dan Kewarganegaraan FIS UNP sebanyak 176 orang dan Dosen Mata Kuliah Hukum Prodi PPKn. Untuk mendapatkan data dari informan yakni mahasiswa dilakukan melalui penyebaran angket sedangkan wawancara mendalam dilakukan pada Dosen. Analisis data yang digunakan melalui tiga tahap yakni reduksi data, penyajian data dan penarikan kesimpulan atau verifikasi.

\section{HASIL DAN PEMBAHASAN}

\section{Gambaran Pembelajaran Ilmu Hukum Mahasiswa Prodi PPKn FIS Universitas Negeri Padang}

Berdasarkan hasil wawancara dengan salah seorang Dosen yang mengajar mata kuliah hukum menjelaskan bahwa proses pembelajaran dalam mata kuliah hukum ini bersifat konvensional artinya ketika mengajar dosen cenderung berceramah, karena dengan berceramah mampu memberikan pemahaman lebih baik kepada mahasiswa. Di samping proses pembelajaran yang berlangsung secara verbal, pembelajaran mata kuliah hukum juga menggunakan metode diskusi kelompok, dengan metode ini mahasiwa mampu berfikir kritis tentang implementasi hukum yang berlaku di Indonesia. Berdasarkan hasil analisis angket dijelaskan bahwa sebanyak 103 orang setuju dan 69 orang sangat setuju dengan adanya pembelajaran ilmu hukum di Prodi PPKn mahasiwa memiliki pengetahuan mengenai adanya peraturan hukum di kampus dan di masyarakat. Sebanyak 117 orang setuju dan 50 orang sangat setuju 
dengan adanya pembelajaran ilmu hukum mahasiswa memiliki pengetahuan mengenai isi dari peraturan hukum tertentu. Sebanyak 109 orang setuju dan 57 orang sangat setuju dengan adanya pembelajaran ilmu hukum mahasiswa memiliki pengetahuan mengenai konsekuensi pelanggaran hukum tertentu.

Sebanyak 100 orang setuju dan 65 orang sangat setuju dengan adanya pembelajaran ilmu hukum mahasiswa memiliki pemahaman dasar mengenai tujuan adanya peraturan hukum tertentu. Sebanyak 110 orang setuju dan 60 orang sangat setuju dengan adanya pembelajaran ilmu hukum mahasiswa memiliki pengetahuan mengenai pola-pola perilaku pelanggaran hukum tertentu. Sebanyak 105 orang setuju dan 58 orang sangat setuju dengan adanya pembelajaran ilmu hukum mahasiswa memiliki perasaan khawatir dan takut melanggar hukum.

Kemudian Sebanyak 108 orang setuju dan 52 orang sangat setuju dengan adanya pembelajaran ilmu hukum mahasiswa memiliki harapan yang baik akan hukum kedepannya. Sebanyak 105 orang setuju dan 60 orang sangat setuju dengan adanya pembelaajran ilmu hukum mahasiswa memiliki kesiapan taat hukum. Sebanyak 108 orang setuju dan 54 orang sangat setuju dengan adanya pembelajaran hukum mahasiswa memiliki kepercayaan akan hukum yang berlaku. Jadi dapat kita pahami bahwa dengan adanya pembelajaran ilmu hukum yang diberikan kepada mahasiswa prodi PPKn memberikan dampak yang baik bagi kesadaran hukum mahasiswa ini terlihat dari pengetahuan, pemahaman, sikap dan perilaku. Agar kesadaran hukum itu tumbah setiap mahasiswa memang harus memiliki pegetahuan, pemahaman, sikap dan perilaku terhadap hukum yang berlaku. Hal ini sesuai dengan pendapat Abdul Wahid (2017:55) menjelaskan bahwa hal utama yang harus ada dalam menumbuhkan kesadaran hukum siswa adalah adanya pengetahuan terhadap peraturan-peraturan hukum. Upaya dalam Meningkatkan Kesadaran Hukum Mahasiswa Prodi PPKn FIS Universitas Negeri Padang

Dalam kesadaran hukum ada beberapa hal yang ditekankan agar kesadaran hukum bisa berlaku sebagaimana mestinya yaitu:

1. Kesadaran hukum harus didasari dengan pengetahuan apa itu hukum, jika seseorang tidak mengetahui apa itu hukum maka tidak akan bisa menjalankan hukum sebagaimana mestinya. Bahwa hukum merupakan hal yang penting untuk masyarakat karena bertujuan untuk menjaga ketertiban umum.

2. Adanya pemahaman akan hukum, pemahaman terhadap hukum merupakan hal yang penting yang harus dimiliki oleh setiap individu sehingga setiap orang mampu menjalankan aturan-aturan yang ada dalam hukum tersebut. Hal ini sesuai dengan pendapat Jain (2014) menjelaskan bahwa dalam mumbuhkan kesadaran hukum sangat penting adanya pemahaman terhadap hukum tersebut. Sehingga ketika seseorang sudah mampu mengambil makna dari suatu peraturan hukum yang berlaku maka ia akan dapat menentukan sikap terhadap hukum tersebut.

3. Kesadaran tentang kewajiban terhadap orang lain, artinya setiap orang mengetahui apa yang boleh dan 
tidak boleh dilakukan kepada orang lain, ketika seseorang melanggar hak orang lain maka itu akan bertentangan dengan aturan atau hukum yang berlaku.

4. Menerima hukum, yakin aturan pasti yang harus ditaati jika hukum ingin berjalan.

Agar keempat point di atas dapat berjalan dengan semestinya dan menumbuhkan kesadaran hukum maka dapat dilakukan beberapa upaya berikut ini:

a. Tindakan, hal ini menjadi salah satu cara utama dan pertama untuk menamankan kesadaran hukum pada mahasiswa atau masyarakat. Tindakan dapat berupa sanksi bagi yang melanggar hukum ataupun penghargaan bagi yang mentaati hukum. Hal ini didukung oleh penelitian Zhussupova (2016:4146) menjelaskan bahwa untuk menumbuhkan kesadaran hukum harus ada mekanisme dalam peraturan konstitusi. Sehingga masyarakat mengetahui dengan jelas bahwa hukum atau konstitusi sifatnya mengikat dan memaksa, mengikat seluruh warga masyarakat untuk mematuhi hukum sehingga ketika terjadi pelanggaran hukum maka akan ada sanksi atau ganjaran dari pelanggaran tersebut.

b. Pendidikan, segala hal tentang pengetahuan, pemahaman, kesadaran hukum orang lain, dan menerima hukum harus disampikan dengan cara yang tepat. Pendidikan merupakan salah satu cara yang tepat. Hal ini dapat dimulai dari lingkungan keluarga, sekolah dan masyarakat secara luas. Hal ini sesuai dengan pendapat McCourt (2013: 16) menjelaskan bahwa kurikulum dalam pembelajaran ilmu hukum (pendidikan hukum) memiliki peran dalam menumbuhkan kesadaran hukum dan pemahaman hukum yang diharapkan. Pendidikan dan pelatihan hukum juga harus diberikan kepada para pendidik sehingga pendidik mampu memahami aturan atau hukum seputar kepatuhan (disiplin) peserta didik (Decker:2017:255)

c. Kampanye, merupakan salah satu bentuk pengenalan terhadap hukum. Ketika seseorang mengenal hukum, ganjarannya ketika melanggar hukum maka akan dikenakan sanksi atau hukum.

Jadi dapat kita pahami bahwa upaya yang dapat dilakukan dalam menumbuhkanm kesadaran hukum mahasiswa maupun masyarakat secara umum dapat dilakukan melalui tindakan, pendidikan maupun kampanye namu hal tersebut akan berjalan jika komponen dalam kesadaran hukum sudah semestinya yakni mahasiswa atau masyarakat harus memiliki pengetahuan tentang aturan-aturan yang berlaku (hukum), memiliki pemahaman tentang isi peraturan hukum, sikap terhadap peraturan hukum dan perilaku sesuai dengan hukum yang berlaku.

\section{KESIMPULAN}

Kesadaran hukum akan tumbuh jika aspek-aspek dalam kesadaran hukum sudah terpenuhi yakni: adanya pengetahuan tentang peraturan hukum, adanya pemahaman tentang isi peraturan hukum yang berlaku, adanya sikap terhadap peraturan hukum dan munculnya perilaku hukum. Upaya yang dapat dilakukan dalam menumbuhkan kesadaran hukum mahasiswa atau amasyarakat dapat 
Journal of Civic Education (ISSN: 2622-237X)

Volume 1 No. 32018

dilakukan melalui tindakan hukum, pendidikan dan kampanye hukum.

\section{DAFTAR PUSTAKA}

Coleman, James.S. 2008. Dasar-dasar Teori Sosial. Bandung: Nusa Media.

Farhana. “Responsive Legal Approach to Law of Human Trafficking in Indonesia", Journal of Social Studies Education Research , Vol. 9 No. 1 p214-227, 2018

Hamzah. " Curriculum and Intructional Challenges in Clinical Legal Education of Indonesian Law School: Breaking the Legacy", Journal of Social Studies Education Research, Vol. 9 No. 3 p215-225, 2018

Kolivoski, Karen M. ; Shook, Jeffrey J.; Johnson, Heath C.; Goodkind, Sara; Fusco, Rachel; Delisi, Matt; Vaughn, Michael G. Applying Legal Socialization to the Child Welfare System: Do Youths' Perceptions of Caseworkers Matter?", Child \& Youth Care Forum, Vol. 45 No. 1 p65-83, 2016

Gostev, Aleksandr N.; Turko, Tamara i.; Shchepanskiy, Sergey B. "Social Mechanisms in Elaborating Russian Educational Policy: Legal Monitoring". International Journal of Environmental and Science Education, Vol. 11 No. 18 p11195-11218, 2016

Nguyen, David H.K.; Collier, Joan; Watts, Angela; Cartwright, Camille; King-Kostelac, Amelia."Examining the Legal Consciousness of Residence Life Staff". Journal of Collage and
University Student Housing, Vol. 44 No. 3 p126-143, 2018

Curro, Gina; Ainswroth, Nussen. "Social Media and Higher Education: Does Digitally Enabled Learning Have a Place in Law Schools?". Journal of the Scholarship of Teacing and Learning, Vol. 18 No. 3 p72-86, 2018

Decker, Jonet R; Pazey, Barbara L. "Case- Based Instruction to Teach Eduators about the Legal Parameters Surrounding the Discipline of Students with Disabilities". Action in Teacher Education. Vol. 39.No. 3 p255273, 2017

Abdulwahid, Muntaha A.; Hamzah, Zaitul Azma Binti Zainon; Hajimaming, Pabiyah; Alkhawaja, Hussein W. “Translating Legal Collocations in Contract Agreements by Iraqi EFL Students- Translators". International Journal of Education and Literacy Studies, Vol. 5 No. 1 p55-68, 2017

Zhussupova, Guldaray B.; Zhailyaubayev, Rassul T. ; Ukin, Symbat K.; Shunayeva, Sylu M.; Nurmagambetov, Rachit G. "Theoretical Issues of the Constitutional Regulation Mechanism". International Journal of Environmental and Science Education, Vol. 11 No. 11 p4146-4153, 2016

McCourt, Alison; Low, Mary; Tappin, Ella. "The Relevance of Business Law Education for Future Accountants: A New Zealand Perpective". E-Journal of Business Education and Scholarship of Teaching. Vol. 7 No. 1 p1-16, 2013 
Jain, Jasmine; Abdullah, Nabilah; Lim, Beh Kian. "Pre Service Science Teachers' Conceptions on the Scientific Theory- Law Relationship: A Phenomenographic Study". Electronic Journal of Science Education. Vol. 18 No. 4, 2014

Soekanto, Soerjono. 1982. Kesadaran Hukum dan Kepatuhan Hukum Suatu Analisis Sosiologi Hukum. Jakarta: CV. Rajawali.

Suparlan, Marzuki. Tanpa tahun. Diklat Kuliah Sosiologi Hukum. Yogyakarta: Fakultas Hukum Universitas Indonesia.

Rahardjo, Sutjipto. 2009. Hukum dan Perilaku. Jakarta: Kompas Media Nusantara

Razak, Yusran (Ed). 2008. Sosiologi Sebuah Pengantar Tinjauan Pemikiran Sosiologi Perspektif Islam. Ciputra: Laboratorium Sosiologi Agama. 